\section{The Cyclicality of Loan Loss Provision in Brazilian Commercial Banks}

\author{
Antônio Maria Henri Beyle de Araújo ${ }^{\dagger}$ \\ Universidade Católica de Brasília - UCB, Brasilia, Distrito Federal, Brazil \\ Paulo Roberto Barbosa Lustosa ${ }^{\Omega}$ \\ Universidade de Brasília, Brasilia, Distrito Federal, Brazil \\ José Alves Dantas ${ }^{¥}$ \\ Universidade de Brasilia, Brasilia, Distrito Federal, Brazil
}

\section{ABSTRACT}

Debates on banking regulation have increasingly given rise to a discussion on the relationship between the loan loss provision and business cycles. Provisioning rules for credit losses for banks in Brazil have mixed system characteristics, which could theoretically lead banks to pro-cyclical or countercyclical behavior, which reinforces the need for research to indicate what has actually been the effect of these provisions in the economy. The purpose of this paper is to analyze the relationship between banks' provisioning for credit losses and business cycles in Brazil, in an attempt to confirm its nature, a condition capable of avoiding potentiating the effects of economic contraction or expansion. Using an econometric model with accounting and macroeconomic variables, the survey involved 91 commercial banks in the period from 2001 to 2012. Confirming that the delay in payments of principal and charges is a key condition for the recognition of banking provisions in Brazil, which highlights its predominantly retrospective nature, the results point to the existence of a pro-cyclical behavior by the banks surveyed, indicating that when GDP is on the rise, provisions tend to fall and vice versa.

Keywords: LLP; Cyclicality; Business cycle; Loans; Commercial banks.

\section{INTRODUCTION}

According to Harrald and Sandall (2010), discussions on banking regulation, whose role is to ensure the stability of the financial system, have involved how the financial system would be accentuating the effects of the expansion and contraction phases. At the heart of the discussion is the concern with pro-cyclicality, which represents the positive correlated movement between a variable and economic activity (BEBCZUK et al., 2010).

According to Longbrake and Rossi (2011), the financial system should cushion business cycles instead of amplifying them. Procyclicality becomes especially a problem, when it accentuates the effect of the fall of the business cycle, favoring the aggravation of crises. Under these conditions, countercyclical rules, which soften economic imbalances, reducing the amplitude of cycles, are welcome.
Corresponding author:

${ }^{\dagger}$ Universidade Católica de Brasília - UCB, Brasília, Distrito Federal, Brazil.

E-mail: antonio.araujo@bcb.gov.br

${ }^{\Omega}$ Universidade de Brasília, Brasília, Distrito Federal, Brazil.

E-mail:prblustosa@gmail.com

${ }^{¥}$ Universidade de Brasília, Brasília, Distrito Federal, Brazil.

E-mail: josealvesdantas@gmail.com

\section{Received: 12/19/2016.}

Revised: 05/19/2017.

Accepted: 06/27/2017.

Published Online: 02/01/2018.

DOI: http://dx.doi.org/10.15728/bbr.2018.15.3.3 
Longbrake and Rossi (2011) highlight the rules of constitution of the loan loss provision as a factor that explains the influence of the financial system on the economy. Provisioning plays an important role in the measurement of receivables, adjusting the book value of these assets to their probable realizable value and allowing the coverage of expected losses.

We have observed that, at the beginning of a downward business cycle, there is little provision by banks. With the worsening of the crisis, provisions will grow, deteriorating the credit situation of credit providers and causing the reduction in the lending level precisely at the moment when the market most needs it.

For Berger and Udell (2004 apud Bouvatier and Lepetit, 2012), an excessive cyclicality of bank credit may lead to an exacerbation of the business cycle, increasing the systemic risk and preventing a more adequate allocation of the resources available for loans.

According to Jackson (1999 apud Bikker and Metzemakers, 2004), when the level of economic activity is declining, the quality of banks' assets tends to deteriorate, increasing their risk exposure. As a consequence, banks are forced to cut loans, which leads to the weakening of economic conditions as a whole.

Studies such as by Bouvatier and Lepetit (2007) and Bikker and Metzemakers (2004), were conducted to investigate the relationship between the loan loss provision and business cycles. In addition to being restricted to specific aspects of the provision, such studies used relatively distinct models and variables, leaving room for further research.

Our proposal is to analyze whether the accounting model of constitution of loan loss provision applicable to commercial banks in Brazil is pro-cyclical, countercyclical or acyclical.

By using an econometric model in data panels, the research involved 91 commercial banks, contemplating the period 2001-2012, which presents both phases of expansion as well as economic retraction. The results indicated the existence of pro-cyclical provisions.

The article is thus structured: in this section we introduce the topic; in the second section we take a look at the current stage of the debate; in the third we discuss the relationship between provision and business cycles; in the fourth we describe the methodology; in the fifth we present and discuss the results, and in the sixth we bring final considerations and suggestions for future studies.

\section{THE STATE OF THE ART}

The analysis of the relationship between loan loss provision and business cycles was explored in several studies. Bikker and Metzemakers (2004), based on the models by Cavallo and Majnoni (2001) and Laeven and Majnoni (2003), found that provisions tend to be substantially larger when GDP growth is lower, reflecting the growing risk of the credit portfolio when the business cycle is in decline.

Handorf and Zhu (2006) researched US commercial banks in the period 1990-2000, identifying a rational behavior in relation to the provision, which reflects both current and forecasted losses. Medium-sized banks are more likely to consider forecasted losses in the provisioning process, in an attitude considered countercyclical. Smaller banks and banks considered as too big to fail are more focused on provision practices that contemplate current losses, in a pro-cyclical attitude.

Bouvatier and Lepetit (2007), in a study conducted in 186 European banks in the period 1992-2004, concluded that the adoption of provisions to cover expected losses (nondiscretionary provisions) causes greater fluctuations in credit, while provisions used for management purposes (discretionary provisions) do not have the same effect. 
BBR

15,3

Boutavier and Lepetit (2012) analyzed how provision rules influence the loan market, concluding that a provision system based on past information increases the pro-cyclicality of market fluctuations. In a provisioning system based on forecasts of future losses, the problem of pro-cyclicality does not exist.

Glen and Modrágon-Vélez (2011), in analyzing the effects of business cycles on the performance of commercial banks' loan portfolios of developing countries in the period from 1996 to 2008, concluded that while economic growth is the main driver of this performance, the effects caused by interest rates are of second order. The authors observed that the relationship between the provisions for losses and economic growth are highly nonlinear only under conditions of extreme economic stress.

\subsection{LOAN LOSS PROVISION IN BANKS}

For Hendriksen and Van Breda (1999), an important element in the evaluation of receivables is the treatment of uncertainty regarding their collection. It is recommended for revenue to be measured by the amount expected to be received, with the provision being the tool that adjusts the book value of the receivables and the result of the entities with accounts receivable.

Glen and Mondrágon-Vélez (2011) conceptualize loan loss provision as expenses recognized in the income statement in contrast to reserves for losses on loans, which are being accumulated in the balance sheet. According to Bikker and Metzemakers (2004), these reserves will be used when the losses occur, being related to the quality of the loan portfolio and the economic fluctuations.

According to Bikker and Metzemakers (2004), accounting rules of the regulatory bodies, taxation and bank behavior (including earnings management and prospective risk management) also influence the provision.

For Cavallo and Majnoni (2001), the provision acts as a shock absorber instrument and must cover the losses expected by banks.

According to Bouvatier and Lepetit (2012), provision rules may be "backward-looking", when based on the losses incurred in the operations and "forward-looking", when based on expected losses.

An example of a "backward-looking" model is the incurred loss model adopted in the United States of America, whose basis is the recognition of losses only if they exist on the balance sheet date. This model requires the initial identification of a situation, known as a "loss event", on which there is a possibility of future loss and whose value can reasonably be estimated, so as to enable the entity to recognize the provision.

An example of a "forward-looking" model is the expected loss model, which recognizes provisions based on expectations of future losses, regardless of the existence of objective evidence.

Provisions may be generic or specific. According to Cavallo and Majnoni (2001), the generic ones are "ex-ante" provisions, related to uncertain future events, and can be highly subjective and manipulable, applicable to all transactions, regardless of loss events. Specific ones are "ex-post" provisions related to specific observable events, such as payment history and write-off of credits as losses.

For Laeven and Majnoni (2003), banks use the loan loss provision to "smooth" income. The advantage of this "smoothing" would be in the reduction of profit volatility, reducing the possibility for banks to consume capital to honor possible losses. With "smoothing", profits will be less affected by the fluctuations of losses during the cycle.

Laeven and Majnoni (2003) warn of the shared view that "smoothing" income has negative connotations, because it modifies the way of evaluating the profit, reducing the comparability of income and damaging shareholder wealth. 
For Laeven and Majnoni (2003), capital restrictions by rules imposed by the regulator, benefits of a fiscal nature, executive remuneration systems and concerns about possible bankruptcy are reasons for the practice of income smoothing by banks.

\subsection{RELATIONSHIP BETWEEN LOAN LOSS PROVISION AND BUSINESS CYCLES}

According to Bikker and Metzemakers (2004), in a period of economic recovery there are more favorable conditions for companies, reducing the probability of losses on bank loans. The opposite situation occurs in periods of recession. As a consequence, banks are expected to reflect such conditions in their decisions, reducing the level of provision in periods of economic expansion and increasing it when the level of economic activity declines.

Bikker and Metzemakers (2004) warn of an alternative perspective, termed as the countercyclical view, which sustains the credit risk is built in times of economic expansion, materializing in periods of economic downturn. In this view, provisions should be positively related to the credit supply cycle, so that banks will recognize the risk of operations in favorable economic periods, constituting provisions for use in bad economic periods.

The "backward-looking" and "forward-looking" models usually present distinct behavior regarding cyclicality. According to Bouvatier and Lepetit (2012), in the "backward-looking" model we observe a pro-cyclical behavior of provisions, since the problems identified in loans in periods of economic expansion are smaller, leading banks to underestimate expected future losses on these loans and forcing them to make large provisions during bad business cycles.

Betancourt and Baril (2009) present justifications for the "incurred loss model" being pro-cyclical. Under favorable economic conditions, few borrowers have difficulties repaying their loans. Thus, historical rates of loss decrease in good economic periods, as there is almost no objective evidence justifying the increase in the volume of provisions, although it is known that future losses will inevitably occur when the business cycle becomes unfavorable. It is because we cannot increase provisions in favorable cycles that banks are obliged to increase them in unfavorable cycles, exactly when they need more income and capital.

According to Bouvatier and Lepetit (2012), in the "forward-looking" provision system, exactly the opposite occurs, which reveals its countercyclical nature.

\subsection{LOAN LOSS PROVISION OF BANKS IN BRAZIL}

According to the Accounting Plan of the National Financial System Institutions - Cosif, banks must set up sufficient provisions to cover possible losses on credit operations.

According to Cosif, institutions should classify their credit operations, in increasing order of risk, at the levels: AA, A, B, C, D, E, F, G and H.

The following information on the debtor and guarantor of the operation should be considered for classification of the operation:

a) economic and financial situation;

b) degree of indebtedness;

c) ability to generate revenue;

d) cash flow;

e) administration and quality of controls;

f) punctuality and delays in payments;

g) contingencies;

h) sector of economic activity; and

i) credit limit. 
BBR

15,3

In the case of an individual debtor, the analysis of income and personal equity should also be considered.

In the definition of the risk level of credit operations, we must also consider the nature and purpose of the transaction, the characteristics of the assurances, particularly regarding adequacy and liquidity, and value.

The classification of operations must undergo periodic reviews. When drawing up income statements and balance sheets, institutions should check for delays in payment of principal or charges, reclassifying the operation, if necessary, as follows:

a) delay between 15 and 30 days: $\mathrm{B}$ level risk, minimum;

b) delay between 31 and 60 days: $\mathrm{C}$ level risk, minimum;

c) delay between 61 and 90 days: D level risk, minimum;

d) delay between 91 and 120 days: E level risk, minimum;

e) delay between 121 and 150 days: $F$ level risk, minimum;

f) delay between 151 and 180 days: $G$ level risk, minimum;

g) delay greater than 180 days: $\mathrm{H}$ level risk.

The operations of the same client or economic group with an amount greater than $5 \%$ of adjusted book value of equity, regardless of delays in payment of principal or charges, must be reviewed every six months, whereas the remaining operations should be re-evaluated once every twelve months, with the exception of those contracted with customers with total responsibility less than 50,000.00 BRL, which may be revised only on the basis of delays, and the original classification should be retained when the revision indicates the classification at a lower risk level.

The provision, being constituted monthly, is calculated according to the classification risk level of credit operations, and their value cannot be lower than the sum resulting from the application of the following percentages on the value of operations:

a) $0.5 \%$ on the value of level A credit operations;

b) $1 \%$ on the value of level B credit operations;

c) $3 \%$ on the value of level C credit operations;

d) $10 \%$ on the value of level D credit operations;

e) $30 \%$ on the value of level E credit operations;

f) $50 \%$ on the value of level $\mathrm{F}$ credit operations;

g) $70 \%$ on the value of level $\mathrm{G}$ credit operations; and

h) $100 \%$ on the value of level $\mathrm{H}$ credit operations.

Cosif does not foresee the constitution of generic provisions, reducing the possibility of occurrence of a countercyclical pattern, even though the fact that the percentage of provision is defined as minimum makes room for additional provisions, at the discretion of the institution.

The provisioning system of Brazilian banks can be considered as a mixed model, because the classification of operations according to their risk level encourages the industry to evaluate the customer's future payment capacity, incorporating a forwardlooking approach. However, past events also influence this evaluation, such as the delay in payment of principal and interest, which makes the model also present characteristics of a "backward-looking" system.

The Brazilian model, therefore, tries to incorporate more predictive criteria for the constitution of the provision, although it is known that the recognition of the provision 
based on delays is able to facilitate the operationalization of the said model. This facility can take the model to a retrospective behavior, typical feature of an incurred loss model.

\section{RESEARCH METHODOLOGY}

\subsection{SAMPLE AND DATA SOURCES}

The sample included the following institutions, according to the classification adopted by the Central Bank of Brazil (BCB):

a) commercial banks, multiple banks with a commercial portfolio, and non-conglomerate savings banks; and

b) conglomerates composed of at least one commercial bank or multiple commercial bank type institution.

Ninety institutions were contemplated, which held, as of December 31, 2012, 84.1\% of the assets of the National Financial System.

The data were taken from the semestrial financial statements, positions of June 30 and December 31, relating to the period 2001-2012.

The other data were obtained from the sites of the Central Bank of Brazil (BCB) and the Brazilian Institute of Geography and Statistics (IBGE) on the Internet.

\subsection{THE MODEL}

We used a linear regression model to make inferences about the relation between the variables of interest, in order to identify how the reserves react to the behavior of the variables that characterize business cycles, since most of the studies on the subject use this type of model, e.g., Cavallo and Majnoni (2001), Bikker and Hu (2002), Laeven and Majnoni (2003), Bikker and Metzemakers (2004), Handorf and Zhu (2006), Bouvatier and Lepetit (2007) and Glen and Mondragón-Velez (2011).

We estimated the following model, based on the panel data method, of the cross-section type:

$$
\begin{array}{r}
P R O V_{i t}=\beta_{0}+\beta_{1} \triangle G D P_{t}+\beta_{2} U N E M P L_{t}+\beta_{3} P R O_{i t}+\beta_{4} \Delta l n L O A_{i t}+\beta_{5} L O A_{i t}+ \\
\beta_{6} E Q_{i t}+\beta_{7} S I Z E_{i t}+\varepsilon_{i t}
\end{array}
$$

where:

- $P R O V_{i t}=$ loan loss provision over the average total assets of banks $i$ in period $t$

- $\triangle G D P=$ real GDP growth in period $t$

- $U N E M P L_{t}=$ unemployment rate in period $t$

- $P R O_{i t}=$ income before taxes, participations and loan loss provisions over the average total assets of banks $i$ in period $t$

- $\triangle \ln L O A_{i t}=$ variation of the balances of loans of banks $i$ in period $t$

- $L O A_{i t}=$ balance of credit operations on the total assets of banks $i$ in period $t$

- $E Q_{i t}=$ equity capital on the total assets of banks $i$ in period $t$

- $S I Z E_{i t}=$ size of banks $i$ in period $t$

The purpose of the model is not to capture an eventual cause and effect relationship between the dependent variable and the independent variables, but rather to identify how the dependent variable behaves in the face of a variation observed in each of the independent variables, especially in macroeconomic variables.

The accounting variables of the model are endogenous in nature. However, their inclusion is absolutely necessary, since the loan loss provision is by its nature, influenced by 
BBR

15,3

252

accounting factors, such as accounts receivables, earnings and shareholders' equity capital. These variables end up functioning as control variables, helping to capture more adequately the relationship between the dependent variable and the independent critical variables of the study (GDP and unemployment).

\subsubsection{THE DEPENDENT VARIABLE}

Most of the models dealing with the relationship between provision and business cycles use provision as a dependent variable. This study follows the same line, defining provision as the net amount of loan loss provision, represented by the difference between the provisions constituted and those reversed in the accounting period.

In order to mitigate the risk of heteroscedasticity in the regression residuals, the dependent variable was scaled by total assets.

\subsubsection{THE INDEPENDENT VARIABLES}

The model includes independent variables that can be classified into three groups: macroeconomic variables (GDP and unemployment); accounting variables of the selected banks (earnings before income tax, profit sharing and loan loss provisions; loans, variations in loans and equity capital); and control variables (bank size).

GDP is the critical variable of the model, being considered in several studies as the most useful indicator to represent the business cycle. It contemplates the half-yearly percentage variation in GDP, at constant prices.

The unemployment rate is another measure representative of the current phase of the business cycle, having been calculated on a semester basis. The indicator represents the unemployment rate of persons aged 10 or over, considering the main metropolitan regions of the Country.

The profits variable, signaling a possible use of provision as an instrument of earnings management, is obtained by dividing the value of earnings before income tax, profit sharing and loan loss provisions by the average total assets in each semester.

The loan growth variable, indicative of the evolution of credit risk, represents the change in the balances of credit operations in each semester, calculated in real terms, having as deflator the General Market Price Index - IGPM. The variation of the loans balance was calculated by the difference of the natural logarithms: $\ln \left(\right.$ loan operations $\left.{ }_{\text {it }} / \mathrm{IGPM}_{\mathrm{it}}\right)-\ln ($ loan operations $_{\text {it-1 }} / \mathrm{IGPM}_{\mathrm{it}-1}$ ).

The loans variable, which is representative of exposure to credit risks, indicates the relative size of banks' loan portfolios. It is obtained by dividing the balance of credit operations accounts by the value of the total assets in each semester.

The equity capital variable indicates a possible use of the provision for capital management and is obtained by dividing the net equity by the total assets in each semester.

The independent variables also had their values divided by the value of the total assets in order to mitigate the risk of heteroscedasticity in the residuals of the regression.

\subsubsection{THE CONTROL VARIABLES}

The variable SIZEit, defined as the natural logarithm of total bank assets, deflated by the IGPM, aims to control the effects of the size of institutions in calculating the provision. Larger banks are expected to make provisions in higher percentages. 


\subsection{SYNTHESIS OF EXPECTED RESULTS (COEFFICIENTS SIGNS)}

Table 1 summarizes the expected results in relation to the behavior and sign of the coefficients related to the explanatory variables, with reference to the hypotheses formulated.

Table 1 . Summary of expected results in relation to explanatory variables.

\begin{tabular}{|c|c|c|}
\hline Variable & Expected Behavior & Algebraic Sign \\
\hline GDP growth & $\begin{array}{l}\text { With the adoption of accounting criteria for provision considered to be mixed, a positive change } \\
\text { in GDP may cause the level of provision to rise or fall, depending on the prevalence of ex-post } \\
\text { criteria on ex-ante criteria, which would indicate a predominantly countercyclical nature, or } \\
\text { the prevalence of ex-ante criteria on ex-post criteria, which would signal a predominantly pro- } \\
\text { cyclical nature. }\end{array}$ & $+/-$ \\
\hline Unemployment rate & $\begin{array}{l}\text { With the adoption of accounting criteria for provision considered to be mixed, a positive } \\
\text { variation in the unemployment rate may increase or decrease the level of provision, depending } \\
\text { on the prevalence of ex-post criteria on ex-ante criteria, which would indicate a predominantly } \\
\text { countercyclical nature, or the prevalence of ex-ante criteria on ex-post criteria, which would } \\
\text { signal a predominantly pro-cyclical nature. }\end{array}$ & $+1-$ \\
\hline Profit/Asset & $\begin{array}{l}\text { Considering that banks use the provision as an instrument of earnings management, it is } \\
\text { expected that a positive variation in earnings before income tax, profit sharing and loan loss } \\
\text { provisions and loan loss provisions will increase the level of provision. }\end{array}$ & + \\
\hline $\mathrm{EQ} /$ Asset & $\begin{array}{l}\text { Considering that banks use provision as an instrument of capital management, it is expected that } \\
\text { a negative variation in equity will increase the level of provision. Thus, a bank would be prone } \\
\text { to provision more when its regulatory capital is below of what is required. This practice is often } \\
\text { more common in capital-deficient banks. }\end{array}$ & - \\
\hline Loans/Asset & $\begin{array}{l}\text { Considering that an increased participation of credit operations in a bank's total investments } \\
\text { represents an increase in its credit risk, it is expected that a positive variation in the ratio of loans } \\
\text { to total assets will increase the level of provision. }\end{array}$ & + \\
\hline Loan variation & $\begin{array}{l}\text { Considering that a positive variation in the volume of credit operations of a bank over time } \\
\text { represents an increase in its credit risk, it is expected that a positive variation in the volume of } \\
\text { credit operations will increase the level of provision. }\end{array}$ & + \\
\hline
\end{tabular}

\subsection{RobUSTNESS TESTING AND PROCEDURES}

We applied the tests Im, Pesaran and Shin - I.P.S, ADF-Fisher and PP-Fisher of unit root to verify the existence of links without logical explanation in the variables, which can generate spurious regressions. The results indicated that the risk of spurious regressions was far.

We used the Pearson correlation matrix to analyze the correlation between the variables, with the objective of avoiding highly correlated variables composing the regression. The results indicated that there was no high correlation between the independent variables of the model.

The results of the variance inflation test between the explanatory variables indicated no evidence of high multicollinearity in the regression data.

We performed the Chow test to test the existence of individual heterogeneity and to evaluate whether the use of panel data is applicable to the study. We found that the results disregarding individual heterogeneity would not be appropriate, justifying the use of panel data.

We proceeded to Hausman Test to define the best panel data method to estimate the regression: fixed effects or random effects. The result showed that we cannot reject the null hypothesis that the model with random effects is the most appropriate for the model.

To analyze the existence of autocorrelation between the residuals of the regression we performed the Durbin-Watson test. The results indicated that the model residues appear to be auto-correlated. To minimize the risks of sectional heteroscedasticity and of autocorrelation in residues, we proceeded to the scaling of the accounting variables of the model and to 
BBR

15,3

the use of the standard method of sectional errors SUR (PSE), which generates robust parameters even when such conditions are present.

\section{RESULTS}

\subsection{DESCRIPTIVE STATISTICS OF THE DEPENDENT VARIABLE}

According to Table 2, from the second half of 2001 to the second half of 2012, banks constituted, on average, half-yearly provision equivalent to $0.83 \%$ of total assets. The maximum amount of the provision was approximately $16.4 \%$ of total assets, whereas the minimum amount represented a reversal of provision equivalent to $5.18 \%$ of total assets. The standard deviation of $1.4611 \%$ of total assets, above the average, indicates that there was great variability in the provision, motivated, in part, by the reversal mechanism. The median, below the mean, indicates an asymmetric distribution to the left of the series of provision.

Table 2. Descriptive statistics of the dependent variable of the model.

\begin{tabular}{lc}
\hline Descriptive Statistics Measures & Variable Provisions/Total Assets \\
\hline Mean & 0.008300 \\
Medium & 0.004374 \\
Maximum Value & 0.164335 \\
Minimum Value & -0.051856 \\
Standard Deviation & 0.014611
\end{tabular}

Source: Authors own elaboration.

\subsection{DESCRIPTIVE STATISTICS OF INDEPENDENT VARIABLES}

According to Table 3, on average only $34.34 \%$ of the funds invested by the banks were used for credit operations. The average participation of own resources in the total investments of the banks, on the other hand, proved to be significant, around $23 \%$ (for a median of $15.51 \%$ ). The average return on assets was approximately $2.25 \%$.

Table 3. Descriptive statistics of the independent variables of the model.

\begin{tabular}{lccccccc}
\hline MEASUREMENT & LOA/TA & $\Delta$ LOA & EQ/TA & EAR/TA & $\Delta$ GDP & UNEMPL & SIZE \\
\hline Mean & 0.343416 & 0.127201 & 0.232025 & 0.022490 & 0.016682 & 0.085476 & 13.99980 \\
Medium & 0.330855 & 0.126800 & 0.155125 & 0.018419 & 0.019618 & 0.083000 & 13.92221 \\
Maximum Value & 1.034382 & 5.692047 & 0.999960 & 0.356774 & 0.047414 & 0.130000 & 20.80693 \\
Minimum Value & 0.000000 & -5.229836 & -0.103769 & -0.183104 & -0.027886 & 0.047000 & 8.245131 \\
Standard Deviation & 0.235621 & 0.501979 & 0.215428 & 0.032615 & 0.017377 & 0.022212 & 2.349774 \\
\hline
\end{tabular}

Where: LOA/TA represents the participation of credit operations in total assets; $\triangle \mathrm{LOA}$, the real growth of credit operations balances; $\mathrm{EQ} / \mathrm{TA}$, the share of equity in total assets; EAR/TA, the share of earnings before income tax, profit sharing and loan loss provisions in total average assets; $\triangle$ GDP, the real growth of gross domestic product; UNEMPL, the unemployment rate; and SIZE, the size of the commercial bank, represented by the natural logarithm of the total assets deflated by the General Market Price Index (Índice Geral de Preços do Mercado - IGPM).

Source: Authors own elaboration.

\subsection{REGRESSION RESULTS}

The coefficient of determination $\left(\mathrm{R}^{2}\right)$ indicates that the independent variables are associated with $15.65 \%$ of the behavior of the dependent variable. The statistic $\mathrm{F}$, with p-value equal to 0.000000 confirms the statistical significance of the set of independent 
variables in the identification of the association between the behavior of the dependent variable and the behavior of the independent variables. These results are in Table 4.

Table 4. Determination and Statistical F coefficients of the model.

\begin{tabular}{lc}
\hline Variables & Value \\
\hline $\mathrm{R}^{2}$ & 0.156524 \\
Adjusted $\mathrm{R}^{2}$ & 0.153061 \\
F- Statistics & 45.19948 \\
P-Value (F) & 0.000000 \\
\hline
\end{tabular}

Source: Authors own elaboration.

All the macroeconomic and accounting variables specific to the banks surveyed, with the exception of the unemployment rate and size, have significant effects on loan loss provisions according to Table 5.

Table 5. Regression results.

\begin{tabular}{|c|c|c|c|c|}
\hline Variable & Coefficient & Standard Deviation & T-statistic & Probability \\
\hline $\mathrm{C}$ & -0.008639 & 0.008003 & -1.079454 & 0.2805 \\
\hline LOA/ASSET & 0.026826 & 0.002575 & 10.41869 & 0.0000 \\
\hline VAR. LOA. & -0.001394 & 0.000734 & -1.898055 & 0.0579 \\
\hline EAR/ASSET & 0.086840 & 0.016986 & 5.112518 & 0.0000 \\
\hline EQ/ ASSET & 0.013791 & 0.004468 & 3.086557 & 0.0021 \\
\hline VAR. GDP & -0.047743 & 0.018623 & -2.563713 & 0.0104 \\
\hline UN. RATE. & -0.017346 & 0.018539 & -0.935625 & 0.3496 \\
\hline SIZE & 0.000377 & 0.000405 & 0.930450 & 0.3523 \\
\hline
\end{tabular}

Where: $\mathrm{C}$ represents the regression constant; LOA/ASSET represents the balances of credit operations of banks over total assets $i$ in period $t$; VAR. LOA. represents the change in the balances of credit operations of banks $i$ in period $t$; EAR/ASSET represents earnings before income tax, profit sharing and loan loss provisions over the average total assets of banks $i$ in period $t$; EQ/ASSET represents the equity capital over the total assets of banks $i$ in period $t$; VAR. GDP represents real GDP growth in period $t$; UN. RATE. Represents the unemployment rate in period $t$; and SIZE represents the size of banks $i$ in period $t$.

Source: Authors own elaboration.

We found the loans variable to be significant, at a significance level of $1 \%$, with a positive coefficient. Thus, when a bank increases the participation of credit operations in total investments, the relationship between the provision and the investments also increases, corroborating the research hypothesis and confirming that the risks tend to grow during the economic expansions. The adoption of such prudent behavior by banks contributes to reducing the effects of possible pro-cyclical behavior.

The loan growth variable was only significant at a significance level of $10 \%$. It is therefore not so safe to say that the behavior of provisions is associated with the variation in the volume of loans. The coefficient showed a negative sign, signaling that provisions tend to decrease when credit operations balances increase. Such a finding runs counter to the assumption that there was a positive relationship between the real growth in the volume of credit operations and provisions.

The variable earnings before income tax, profit sharing and loan loss provisions were also significant, at a significance level of $1 \%$, indicating that variations in profit are related to the behavior of provisions. The positive sign of the coefficient indicates the growth of the provision when profit increases and vice versa, corroborating the research hypothesis and signaling the practice of earnings management.

The net equity variable was significant at a significance level of $1 \%$, but presented a positive sign, contrary to the hypothesis of using the provision for capital management. Thus, banks increase the value of the provision whenever equity reveals more comfortable 
BBR

15,3

amounts. Such procedure may be due to the fact that commercial banks historically have reference equity higher than that required by the $\mathrm{BCB}$, together with the absence of the generic provision instrument in the country's regulations.

At a significance level of $1 \%$, the coefficient of the GDP variable was significantly negative, indicating a pro-cyclical behavior of banks. When GDP grows, provisions tend to fall and vice versa, reflecting pro-cyclical behavior. The result indicates the absence of an efficient mechanism for prospective risk assessment in Brazil.

The unemployment rate variable was not significant, contrary to expectations.

The control variable was also not significant, indicating that there is no relation between the size of commercial banks and provisions for bad debtors in Brazil.

In order to evaluate whether public and private banks adopt different behaviors in relation to the loan loss provision, two sub-panels were set up. One contemplated private banks, accounting for about $90 \%$ of the sample banks. The other grouped the remaining 10\% (public banks). The results are shown in Tables 6 and 7.

Table 6. Regression results - Public Banks.

\begin{tabular}{ccccc}
\hline Variable & Coefficient & Standard Deviation & T-statistic & Prob. \\
\hline C & 0.011326 & 0.007956 & 1.423526 & 0.1563 \\
LOA/ASSET & 0.007188 & 0.005437 & 1.322237 & 0.1878 \\
VAR. LOA. & -0.007745 & 0.003547 & -2.183804 & 0.0303 \\
EAR/ASSET & 0.133738 & 0.042445 & 3.150811 & 0.0019 \\
EQ/ ASSET & -0.007168 & 0.012555 & -0.570872 & 0.5688 \\
VAR. GDP & -0.017280 & 0.020488 & -0.843386 & 0.4001 \\
UN. RATE. & -0.005274 & 0.022950 & -0.229795 & 0.8185 \\
SIZE & -0.000483 & 0.000424 & -1.140787 & 0.2555 \\
\hline
\end{tabular}

Where: C represents the regression constant; LOA/ASSET represents the balances of credit operations of banks over total assets $i$ in period $t$; VAR. LOA. represents the change in the balances of credit operations of banks $i$ in period $t$; EAR/ASSET represents earnings before income tax, profit sharing and loan loss provisions over the average total assets of banks $i$ in period $t$; EQ/ASSET represents the equity capital over the total assets of banks $i$ in period $t$; VAR. GDP represents real GDP growth in period $t$; UN. RATE. represents the unemployment rate in period $t$; and SIZE represents the size of banks $i$ in period $t$.

Source: Authors own elaboration.

Table 7. Regression results - Private Banks.

\begin{tabular}{|c|c|c|c|c|}
\hline Variable & Coefficient & Standard Deviation & T-statistic & Prob. \\
\hline $\mathrm{C}$ & -0.011775 & 0.008837 & -1.332394 & 0.1829 \\
\hline LOA/ASSET & 0.028375 & 0.002711 & 10.46740 & 0.0000 \\
\hline VAR. LOA. & -0.001379 & 0.000734 & -1.878988 & 0.0604 \\
\hline EAR/ASSET & 0.086946 & 0.017220 & 5.049270 & 0.0000 \\
\hline EQ/ ASSET & 0.015072 & 0.004605 & 3.272531 & 0.0011 \\
\hline VAR. GDP & -0.051106 & 0.020410 & -2.503985 & 0.0124 \\
\hline UN. RATE. & -0.021871 & 0.020234 & -1.080908 & 0.2799 \\
\hline SIZE & 0.000581 & 0.000453 & 1.282602 & 0.1998 \\
\hline
\end{tabular}

Where: $\mathrm{C}$ represents the regression constant; LOA/ASSET represents the balances of credit operations of banks over total assets $i$ in period $t$; VAR. LOA. represents the change in the balances of credit operations of banks $i$ in period $t$; EAR/ASSET represents earnings before income tax, profit sharing and loan loss provisions over the average total assets of banks $i$ in period $t$; EQ/ASSET represents the equity capital over the total assets of banks $i$ in period $t$; VAR. GDP represents real GDP growth in period $t$; UN. RATE. represents the unemployment rate in period $t$; and SIZE represents the size of banks $i$ in period $t$.

Source: Authors own elaboration. 
The regression of the sub-panel of public banks presented $\mathrm{R}^{2}$ of approximately $13.45 \%$, with F statistics of 0.000409 .

Compared to the panel of commercial banks, the sub-panel of public banks presented statistically different results. The variables loans, equity and GDP were no longer significant for public banks. The loan variation variable, on the other hand, proved to be significant at a lower level of significance (fell from $10 \%$ to $5 \%$ ), maintaining the negative coefficient. The variable earnings before income tax, profit sharing and loan loss provisions remained significant at 5\%, also showing a positive coefficient, which signals the practice of earnings management by public banks. Regarding the variables unemployment and size, there are no differences in relation to the result obtained for all commercial banks, with both variables being non-significant.

The regression of the sub-panel of private banks presented $\mathrm{R}^{2}$ of approximately $16.21 \%$, with F statistics of 0.000000 .

As for the level of significance and signs of the coefficients of the variables of the subpanel of private banks, the results were the same as those of the panel with all commercial banks.

In order to confirm whether domestic and foreign banks adopt different behaviors in relation to the provision, we also set two subpanels based on this classification. A sub panel covered the national banks, accounting for approximately $63 \%$ of the sample banks, while the other grouped the remaining $37 \%$ (foreign banks). The results are shown in Tables 8 and 9 .

Table 8. Regression results - National Banks.

\begin{tabular}{ccccc}
\hline Variable & Coefficient & Standard Deviation & T-statistic & Prob. \\
\hline C & 0.008219 & 0.008525 & 0.964034 & 0.3352 \\
LOA/ASSET & 0.019718 & 0.003003 & 6.565544 & 0.0000 \\
VAR. LOA. & -0.002718 & 0.001671 & -1.626868 & 0.1040 \\
EAR/ASSET & 0.132745 & 0.024017 & 5.527008 & 0.0000 \\
EQ/ ASSET & -0.005881 & 0.004747 & -1.239041 & 0.2156 \\
VAR. GDP & -0.046527 & 0.022223 & -2.093685 & 0.0365 \\
UN. RATE. & -0.060093 & 0.022432 & -2.678866 & 0.0075 \\
SIZE & -0.000172 & 0.000419 & -0.409265 & 0.6824 \\
\hline
\end{tabular}

Where: $\mathrm{C}$ represents the regression constant; LOA/ASSET represents the balances of credit operations of banks over total assets $i$ in period $t$; VAR. LOA. represents the change in the balances of credit operations of banks $i$ in period $t$; EAR/ASSET represents earnings before income tax, profit sharing and loan loss provisions over the average total assets of banks $i$ in period $t$; EQ/ASSET represents the equity capital over the total assets of banks $i$ in period $t$; VAR. GDP represents real GDP growth in period $t$; UN. RATE. represents the unemployment rate in period $t$; and SIZE represents the size of banks $i$ in period $t$.

Source: Authors own elaboration.

Table 9. Regression Results - Foreign Banks.

\begin{tabular}{|c|c|c|c|c|}
\hline Variable & Coefficient & Standard Deviation & T-statistic & Prob. \\
\hline $\mathrm{C}$ & -0.037015 & 0.016221 & -2.281967 & 0.0229 \\
\hline LOA/ASSET & 0.041164 & 0.006514 & 6.319301 & 0.0000 \\
\hline VAR. LOA. & -0.001180 & 0.000742 & -1.590644 & 0.1123 \\
\hline EAR/ASSET & 0.031289 & 0.015946 & 1.962188 & 0.0502 \\
\hline EQ/ ASSET & 0.032438 & 0.008037 & 4.036136 & 0.0001 \\
\hline VAR. GDP & -0.043107 & 0.026708 & -1.614021 & 0.1071 \\
\hline UN. RATE. & 0.050096 & 0.031027 & 1.614606 & 0.1070 \\
\hline SIZE & 0.001475 & 0.000933 & 1.580703 & 0.1145 \\
\hline
\end{tabular}

Where: $\mathrm{C}$ represents the regression constant; LOA/ASSET represents the balances of credit operations of banks over total assets $i$ in period $t$; VAR. LOA. represents the change in the balances of credit operations of banks $i$ in period $t$; EAR/ASSET represents earnings before income tax, profit sharing and loan loss provisions over the average total assets of banks $i$ in period $t$; EQ/ASSET represents the equity capital over the total assets of banks $i$ in period $t$; VAR. GDP represents real GDP growth in period $t$; UN. RATE. represents the unemployment rate in period $t$; and SIZE represents the size of banks $i$ in period $t$.

Source: Authors own elaboration. 
BBR

The regression of the sub-panel of the national banks presented $\mathrm{R}^{2}$ of approximately $18.60 \%$, with F statistics of 0.000000 .

Compared to the panel with all banks, the subpanel of the national banks presented statistically different results in three variables. The loan growth variable was no longer significant at a significance level of $10 \%$ indicating that the percentage variation in loan balances is not related to the percentage of provisions constituted by banks with national control capital. The variable equity was also not significant, whereas the variable unemployment rate became significant at a significance level of $1 \%$.

The regression of the sub-panel of foreign banks presented $\mathrm{R}^{2}$ of approximately $47.40 \%$, with $\mathrm{F}$ statistics of 0.000000 .

In relation to banks with foreign controlled capital, compared to the results of the panel with all commercial banks, the loan growth variable was also no longer significant at a significance level of $10 \%$, the variable earnings before income tax, profit sharing and loan loss provisions was no longer significant at a significance level of $5 \%$ to be significant at a significance level of $10 \%$ and the variable GDP is no longer significant at a significance level of $10 \%$. Regarding the other variables, we found no significant differences.

\section{FINAL CONSIDERATIONS}

The constitution of loan loss provisions allows users of accounting information to make a safer forecast of the net cash flows of an entity, in order to evaluate the prospect of return on invested capital.

The provision also allows the timely recognition of the depreciation of current duties, serving as an indicator of the quality of the receivables portfolio of an entity.

The provision causes the early recognition of losses, forming a reserve of value to be used when these losses occur. Early recognition of these losses mitigates the impacts of future economic crises.

The problem of provision lies in its subjectivity, since its calculation depends essentially on the use of estimates and other factors that are beyond the control of entities, among them the taxation and the macroeconomic environment. The problem of provision lies in the difficulty of evaluating the receivable's credit risk.

Issues related to the provision grow in proportion when it comes to commercial banks. Considering that credit is the activity that best represents this segment, issues related to the definition of adequate provision rules gain in interest and importance.

A controversial aspect of the provision concerns the issue of cyclicality. At the heart of this question is the definition of the result that each institution must present at the end of the accounting period. While some argue that such a result should only contemplate the result of the current period (from the perspective of the loss incurred), others argue that the result anticipates future events (from the perspective of the expected loss). The issue is whether or not to adopt a more forward-looking provision.

Studies such as Bikker and $\mathrm{Hu}$ (2002), Laeven and Majnoni (2003) and Bikker and Metzemakers (2004) revealed that the choice between a provision model based on incurred losses and a model based on expected losses can determine the behavior of the provision before the business cycles. The expectation was that the first model was leading to a procyclical provision. Thus, when the economy was doing well, provisions would tend to be decreasing. On the other hand, it was expected that the second model would culminate in a 
countercyclical provision. Thus, when the economy was performing well, provisions would tend to be increasing.

This research investigated whether the provision model adopted by banks in Brazil, considered mixed because it presents characteristics of expected loss and incurred loss, would be countercyclical or pro-cyclical.

The hypothesis was that the loan loss provisions based on the mixed model adopted in Brazil can present both a negative relation and a positive relation with business cycles, depending on the prevalence of prospective or retrospective information in the systems used by banks to calculate these provisions.

Based on the linear regression models used in previous studies, we developed an econometric model capable of identifying the relation between provision and business cycles. Considering accounting and macroeconomic variables, the assumption of the model was that the provision may be being influenced essentially by the following elements: management of credit risk; earnings management; capital management; GDP behavior and unemployment rate behavior.

We used two variables to identify the relationship between provision and business cycles: the real GDP variation and the unemployment rate.

Contrary to expectations, the unemployment rate did not turn out to be a statistically significant variable. It should be stressed that studies such as Bikker and Metzemakers (2004) already indicated that the unemployment rate is not the best proxy to evaluate the relationship between provision and business cycles.

GDP has turned out to be the variable that best reflects the cyclicality of accounting phenomena, having been pointed out as the critical variable in all the studies that subsidized this research. In this study, this variable was also statistically significant, at a significance level of practically $1 \%$.

Only when the public banks were separated from the private ones, and the national banks from foreign ones, the GDP presented a distinct result, not proving to be significant in the case of public and foreign-owned banks. With regard to private banks and those of national capital, the GDP variable proved to be significant.

Regarding the sign of the coefficient of the GDP variable, main focus of this research, the study revealed a pro-cyclical provision, indicating that, despite the general rule in Brazil being the constitution of "forward-looking" provisions, the delays in payment of principal and interest installments, typical of "backward-looking" provision models end up prevailing. As for the practice of earnings management, it is assumed to be a reality for commercial banks operating in Brazil, since the variable earnings before income tax, profit sharing and loan loss provisions was significant, at a significance level of $1 \%$ and presented a positive coefficient, indicating that provisions tend to grow whenever banks' earnings increase.

We emphasize that the earnings management, debatable in certain aspects, can serve as a counterpoint to pro-cyclical provisions, mitigating their effects on the current phase of the business cycle.

The practice of capital management has also not turned out to be a reality. Despite being significant at a significance level of $1 \%$, the mentioned variable showed a positive coefficient, indicating that the higher the share of equity over total assets, the higher the provision by banks. We assume that the comfortable level of capitalization presented by banks (on average, $23.20 \%$ of total assets) is inducing them to increase the level of provision 
BBR

15,3

whenever the net equity presents positive variations, and this represents a conservative procedure that contrasts with the constitution of pro-cyclical provisions.

The size variable was not statistically significant, indicating that the size of the banks does not seem to influence the level of provision.

The results corroborate previous studies by Bikker and $\mathrm{Hu}$ (2002), Laeven and Majnoni (2003) and Bikker and Metzemakers (2004), in the sense that the increase in provisions depends heavily on the business cycle and that banks are likely to delay the recognition of provisions for bad credits as much as they can, recording them exactly at the moment when the economic retraction comes to settle. Another similarity of the results of this research with these studies is the finding that the effect of pro-cyclicality is usually mitigated by the increase in the provision in times when profits are higher (earnings management practice).

For future studies, we suggest conducting this study applying different econometric models, which may incorporate other explanatory variables, especially those related to the recording of delays in the payment of principal and interest on credit operations, and the accounting recognition of losses.

\section{REFERENCES}

Bebczuk, R., Carrera, J., \& Sangiácomo, M. (2010). A new look into credit procyclicality: International panel evidence. In BIS Consultative Council for the Americas Conference on "systemic risk, bank behavior and regulation over the business cycle". Buenos Aires/Argentina.

Berger, A., Udell, G. (2004). The institutional memory hypothesis and the procyclicality of bank lending behavior. Journal of Financial Intermediation, 13, 458-495.

Betancourt, L., \& Baril, C. P. (2009, october/november). Accounting for Loan Losses: Is Dynamic Provisioning the Answer? Bank Accounting \& Finance, 22(6), 9-16. Available on: $<$ http://connection.ebscohost. com/c/articles/44680540/accounting-loan-losses-dynamic-provisioning-answer $>$. Accessed on: 15 jun. 2016.

Bikker, J. A., \& Hu, H. (2002). Cyclical patterns in profits, provisioning and lending of banks and procyclicality of the new Basel capital requirements. Banca Nazionale del Lavaro Quaterly Review 55(221), 143 175. Available on: <https://www.dnb.nl/binaries/ot039_tcm46-146052.pdf>. Accessed on: 14 nov. 2015.

Bikker, J. A., \& Metzemakers, P. A. J. (2004, march). Bank provisioning behaviour and procyclicality. Journal of International Financial Markets, Institutions \& Money, 209, 1-17. doi: 10.1016/j.intfin.2004.03.004.

Bouvatier, V., \& Lepetit, L. (2007). Banks' procyclical behavior: Does provisioning matter? Journal of International Financial Markets, Institutions \& Money, 18, 513-528. doi: 10.1016/j.intfin.2007.07.004.

Bouvatier, V., \& Lepetit, L. (2012, july). Provisioning Rules and Bank Lending: A Theoretical Model. Journal of Financial Stability, 8(2), 25-31. Available on: $<$ http://ssrn.com/abstract $=1148314>$. Accessed on: 28 nov. 2015.

Cavallo, M., \& Majnoni, G. (2001, june). Do Banks Provision for Bad Loans in Good Times? Empirical Evidence and Policy Implications. World Bank Policy Research Working Paper No 2.619. Available on: $<$ http://elibrary.worldbank.org/doi/abs/10.1596/1813-9450-2619>. Accessed on: 10 abr. 2016.

Glen, J., \& Mondragón-Vélez, C. (2011, january). Business Cycle Effects on Commercial Bank Loan Portfolio Performance in Developing Economies. Available on: $<$ http://papers.ssrn.com/sol3/papers.cfm?abstract_ $\mathrm{id}=1754672>$. Accessed on: 20 jun. 2016.

Handorf, W. C., \& Zhu, L. (2006, spring). US Bank Loan-Loss Provisions, Economic Conditions, and Regulatory Guidance. Journal of Applied Finance, 16(1), 97-114. Available on: <http://search.proquest.com/openview/ee52 c0978ed6e519591ff513944a8a54/1?pq-origsite=gscholar\&cbl=26518>. Accessed on: 25 jun. 2016.

Harrald, P., \& Sandall, T. (2010, october). Adressing Pro-cyclicality. Asia-Risk, 70-72. Available on: < http:// www.risk.net>. Accessed on: 25 abr. 2016.

Hendriksen, E. S.; Van Breda, M. F. Teoria da Contabilidade. São Paulo: Atlas, 1999.

Jackson, P. (1999). Capital requirements and bank behauvior: the impact of the Base Accord, Working Papers $\mathrm{n}^{\mathrm{o}}$ 1, Basel Committee on Banking Supervision. Available on: <http://www.bis.org $>$. Accessed on: 22 nov. 2015.

Laeven, L., \& Majnoni, G. (2003, april). Loan loss provisioning and economic slowdowns: too much, too late? Journal of Financial Intermediation, 12(2), 178-197. Available on: $<$ http://www.sciencedirect.com/ science/article/pii/S1042957303000160>. Accessed on: 10 fev. 2016. 
Longbrake, W. A., \& Rossi, C. V. (2011, july). Procyclical versus Countercyclical Policy Effects on Financial Markets. Study prepared for the Anthony T. Cluff Fund. The Financial Services Roundtable. Financing America's Economy. Available on: <http://www.fsround.org/fsr/pdfs/cluff/CountercyclicalPE.pdf $>$. Accessed on: 12 fev. 2016. 